\title{
IN THE WAKe of Irregular Arrivals: Changes to the Canadian Immigration Detention System
}

\author{
Stephanie J. Silverman
}

\begin{abstract}
This article seeks to address the policies, practices, and conditions of immigration detention in Canada. The article surveys detention worldwide, its promulgation in Canada, and changes ushered in via 2012 policy innovations. Focusing on mandatory detention and its relationship to the Designated Countries of Origin policy, the article also demonstrates the disproportionality of the Canadian government's response to recent arrivals of people migrating by boat. The article emphasizes the dangers of establishing mandatory detention provisions and questions the justifcations provided by defenders of the policies.

\section{Résumé}

Cet article examine les politiques, les pratiques et les conditions de détention liée à l'immigration au Canada. Après un survol des différentes pratiques de détention dans le monde, on y examine son établissement au Canada ainsi que ses transformations dans le cours du renouvellement des politiques en 2012. En se concentrant sur la détention obligatoire et ses liens avec la politique des Pays d'origine désignés (POD), l'article nous démontre le caractère disproportionné de la réponse du gouvernement canadien à l'arrivée récente d'immigrants par bateau. Cet article fait ressortir les dangers d'établir des dispositions de détention obligatoire, et remet en question les justifications développées par les tenants de ces politiques.
\end{abstract}

\section{Introduction}

$\mathrm{I}$ n June 2009, minister of citizenship, immigration and multiculturalism Jason Kenney told the House of Commons that "living conditions at detention centres are like those at a two-star hotel with a bit of security." Kenney's florid language was perhaps based on ignorance, or perhaps meant to mislead the press and the public at large over the conditions in detention. Either way, his comments obfuscated the reality of life inside a detention centre and downplayed the trauma of liberty deprivation based on non-citizenship status. This article seeks to correct such oversimplifications of detention practices and conditions in Canada. It aims to refocus attention on undoing the hysteria around people who migrate by boat. The article emphasizes the dangers of C-31, the Protecting Canada's Immigration System Act (an amendment to IRPA)'s mandatory detention provisions and the transparency of justifications provided by Kenney and other defenders of the policy based on deterrence.

This article begins by examining how the Canadian government instrumentalized hysteria encircling a small number of boat arrivals to expand and accelerate its detention powers. C-31's innovation of creating risk-based categorizations of large swaths of people through the creation of a list of Designated Countries of Origin (DCOs) is here highlighted in relation to mandatory detention. After reviewing how Canadian detention policy typically plays out, the article notes a number of criticisms of the detention system, including its effects on children and other vulnerable people. The article finds that the contradiction of mandatory detainees as being the most damaged by their experiences 
in detention but also the most likely to be released into Canadian society make this policy a confusing and incoherent course for Canada to be following.

\section{Arrivals by Boat and the Advent of Mandatory Detention in Canada}

The history of asylum seekers and migrants using boats to reach Canada's shores is not long. In 1914, the government turned away more than 300 Sikh Indian nationals on board the Komagata Maru. When the ship eventually arrived back in Calcutta, 20 people were killed in a riot and others were detained and tortured. In 1939, 936 Jewish refugees were sent back to Europe after their ship, the SS St. Louis, was refused landing in Cuba, the United States, and eventually Canada. Many of the Jewish refugees were arrested upon landing and dispatched to death in concentration camps. While the Canadian government issued an informal apology in 2008 for what happened with (to?) the Komagata Maru passengers, it has yet to issue an official apology for rejecting the SS St. Louis, save for a memorial to the Jewish refugees erected at Pier 21 in Halifax in 2011.

In the modern period, eight ships have arrived collectively ferrying about 1,500 people: in 1986, 152 Tamils landed off the east coast of Newfoundland; in 1987, 174 Sikhs landed in Nova Scotia, prompting an emergency summer recall of Parliament; four ships carrying just under 600 Chinese migrants came to British Columbia's coast in 1999; and the two most recent cases-MV Ocean Lady and MV Sun Seawhich brought 575 Tamils to British Columbia in October 2009 and August 2010, respectively. Cumulatively, these eight vessels have conveyed 0.2 per cent of total refugee arrivals in Canada over the past 25 years. $^{2}$

\section{C-31's Mandatory Detention Provision}

Canadian detention centres house a variety of de facto mandatory detainees. These people include migrants posing flight or security risks or who have not proven their identities and who could not find sureties in Canada; postsentence, pre-removal offenders transferred directly to prison to await deportation; nationals from DCOs or other migrants with "manifestly unfounded" cases put on a "fasttrack" process; and Security Certificate detainees. There are also people who are legally or effectively stateless, such as Baha'i practitioners from Iran and Palestinians in the first category, and North Korean and Somali nationals in the second. Yet it was partially in response to the recent landings of the MV Ocean Lady and MV Sun Sea, and partially to complement its deterrence of unwanted migration agenda, that the Canadian government moved to formalize its use of mandatory immigration detention. C-31, the Protecting Canada's Immigration System Act (an amendment to IRPA), was introduced in February 2012 and eventually passed that December.

Under C-31, the minister of public safety may designate two or more foreign nationals as a group of "irregular arrivals" on the basis that they cannot be examined in a timely manner or on suspicions of "smuggling." Such groups are given a two-week review of refugee admissibility. If the Designated Foreign Nationals (DFN) classification goes through, the group is liable for a one-year period of detention for all persons aged 16 or older; the minister will use discretionary power to decide whether to detain children under 16 or to forcibly separate them from accompanying parents for one year. The 9 May 2012 amendments to Bill C-31 introduced the possibility of conducting a review every 180 days.

DFN stigmatization continues after release from detention. Even if the Immigration and Refugee Board finds that they are persons in need of protection, there is a five-year bar on DFNs applying for permanent residence. DFNs face several consequences as a result of their designation during this five-year period: prohibition from family reunification; requirements to report regularly to immigration authorities for questioning and to produce unspecified documents on demand; and a ban from travelling outside Canada for any reason. ${ }^{3}$

Within six months of its becoming legislation, the minister of public safety has used the "irregular arrivals" designation once, in relation to a group of Romanian asylum seekers in December 2012. This group opted to return to Romania rather than press their cases to stay in Canada and endure the year in detention.

\section{The Designated Countries of Origin List}

After repeatedly imploring the overloading of the refugee determination system by "bogus claimants" and "fraudsters," particularly in relation to the Hungarian Roma or those fleeing the violence in Mexico, the government introduced the concept of Designated Countries of Origin into Canadian legislation through C-31. DCOs are presumed to be "safe" countries that "do not normally produce refugees, have a robust human rights record and offer strong state protection." 4 The minister of citizenship, immigration and multiculturalism designates countries as DCOs on the basis of quantitative factors (a rejection rate of at least 75 per cent (including withdrawn and abandoned cases), or a withdrawn and abandoned rate of at least 60 per cent), or on the basis of the minister's opinion that the country exhibits the hallmarks of a refugee-protecting country, including an independent judiciary, enjoyment of democratic rights, etc. ${ }^{5}$

How does a refugee claimant from a DCO apply for protection in Canada? The Canadian government expects to 
hold hearings on refugee claims of DCO nationals within $30-45$ days after referral of the claim to the IRB, as opposed to the 6o-day timeframe for other refugee claimants. Unlike regularly streamed claimants, failed DCO claimants will neither have access to the Refugee Appeal Division nor be permitted to apply for a work permit upon arrival in Canada. ${ }^{6}$ Legal aid reductions announced by the Canadian government in April 2013 mean that asylum claimants in Ontario who originate from any of the DCO safe countries may no longer be entitled to legal aid and representation at their hearings.? Of course, a DCO claimant is not an automatic candidate for detention, but certain situations predispose such claimants to the possibility. In any event, the creation of a DCO list in C-31 and the new timelines make it "very difficult to file a claim" and ensure that "certain groups of asylum seekers will be excluded from the system and returned to their countries of origin." 8

The original December 2012 list of 25 DCOs had been expanded to 37 countries as of June 2013. Included in this list are the United States, Mexico, and most countries in the European Union. Some of the choices of DCOs have been met with outcry from the legal and advocacy communities. The addition of Hungary to the list has been particularly protested. At a press conference on 14 December 2012, Minister Kenney defended this choice by arguing that " $95 \%$ of claims in 2011 were fraudulent. They were either abandoned, withdrawn, or refused." The Canadian Association of Refugee Lawyers disputes this claim, suggesting instead that the 95 per cent number ignores both the fact that almost 3,000 of the 4,400 claims (68 per cent) had not been decided at the time of the press conference, and also the 18 per cent rate of acceptance for Hungarian claims heard at the IRB. Indeed, the mounting evidence that Hungary is not able to provide protection for vulnerable people from racist and anti-Semitic attacks within its borders 9 leads some refugee advocates to believe that the addition of Hungary to the DCO list was a specious effort to curb the influx of Roma into Canada. ${ }^{10}$

The level of discretionary decision-making afforded to the Minister of Citizenship, Immigration and Multiculturalism in crafting the DCO list is high. As mentioned, the minister sets both the quantitative and qualitative standards for inclusion. There is no public conversation to debate and justify the percentage of rejected cases or transparency of the judiciary that lead to a country being found not to produce refugees. Also worrying is the fact that the minister can add more countries to the DCO list at any time, also without public consultation. More generally, as Petra Diop points out, the DCO policy is "profoundly reductionist and allows for entire groups of refugee claimants to be labeled as 'frauds' on the basis of hailing from a Designated Country of Origin."11

\section{Conditions in Immigration Detention Centres}

Internationallaw generally permits the detention of migrants, pending admissions or deportations, and considers it to be administrative, non-punitive, and ancillary to immigration control. ${ }^{12}$ It is understood as a second-best product of immigration enforcement meant to safeguard other aspects of control, including deportation. International law sets limits on detention according to principles of proportionality, due diligence, and non-arbitrariness. ${ }^{13}$ Detention should be used thoughtfully and as a last resort. ${ }^{14}$ Individualized assessments should take into account the individual's personal history and risk of absconding before a detention decision is made. The detention of vulnerable peopleincluding unaccompanied elderly persons, survivors of torture or trauma, persons with mental or physical disabilities, pregnant or nursing women, and minors-should be especially avoided. Before resorting to detention, states must ensure that a range of alternative, less restrictive, non-custodial measures are available; they must also demonstrate that these so-called alternatives to detention programs will not be effective. ${ }^{15}$ It is unclear how these issues of concern can be addressed in the context of a mandatory detention provision.

Discretionary detention policy in Canada is targeted primarily at three groups of people: (1) "irregular migrants," or foreigners who have been found by a proper procedure to have either entered illegally without having had a preauthorized visa or who are otherwise by law obliged to depart; (2) asylum seekers prior to a final decision on their claims to protection under the 1951 Geneva Convention Relating to the Status of Refugees and its 1967 Protocol (Geneva Convention); and (3) asylum seekers whose applications for Geneva Convention protection have been rejected by the destination state. ${ }^{16}$ The majority may be paroled or released on bond, but some are required to remain in detention until a decision can be reached on removal. This latter group is effectively subject to indefinite detention, and the "unknowingness" of this open-ended detention without time limits can present difficulties akin to mental torture. ${ }^{17}$

Detention is a civil procedure. Nevertheless, it often (intentionally) resembles criminal incarceration. Dora Schriro acknowledged as much in a report released shortly before the completion of her tenure as director of the Office of Detention Policy and Planning in the United States:

As a matter of law, Immigration Detention is unlike Criminal Incarceration. Yet Immigration Detention and Criminal Incarceration detainees tend to be seen by the public as comparable, and both confined populations are typically managed in similar ways. Each group is ordinarily detained in secure facilities with hardened perimeters in remote locations at considerable distances from 
counsel and/or their communities. With only a few exceptions, [detention] facilities ... were originally built, and currently operate, as jails and prisons to confine pre-trial and sentenced felons. Their design, construction, staffing plans, and population management strategies are based largely upon the principles of command and control. Likewise, [the United States] adopted standards that are based upon corrections law and promulgated by correctional organizations to guide the operation of jails and prisons. ${ }^{18}$

In his 2008 report to the UN Human Rights Council, the UN special rapporteur on the human rights of migrants observed the escalation of what is referred to in the academic context as a "crimmigration crisis." 19 The special rapporteur specifically cited detention as evidence of this trend: "It is important that irregular migration be seen as an administrative offence and irregular migrants processes on an individual basis. Where possible, detention should be used only as a last resort and in general irregular migrants should not be treated as criminals. The often erratic and unlawful detention of migrants is contributing to the broader phenomenon of the criminalization of irregular migration." ${ }^{20}$

Detention centres throughout the Western world are characterized by conditions that jeopardize the dignity of detainees. Common problems include inadequate medical, psychological, and hygienic care; subcontracting of services to ill-equipped private firms; and guard misconduct. ${ }^{21}$ Significantly, attention is rarely paid to rectifying the mental debilitation wrought by stays in immigration detention centres. Psychological distress indictors amongst detainees include "depression, suicidal ideation, posttraumatic stress, anxiety, panic, and physical symptoms," particularly when "compared with compatriot asylum seekers, refugees, and immigrants living in the community."22

There is a growing body of research and media reports concluding that long-term detention has adverse mental health outcomes for detainees. ${ }^{23}$ Time in detention is positively associated with severity of the detainee's distress and a persistent negative impact on mental health after release. ${ }^{24}$ This finding is particularly important in states such as Canada that do not have official maximum time limits prescribed by law. This finding should be further contextualized against the background of some states reporting that the majority of successful deportations are effected in the first weeks and months of detention; the longer detention lasts, the less likely the outcome will be deportation, the presumed chief purpose of detention. ${ }^{25}$ Therefore, mandatory detainees are also probable candidates for eventual release into the community, a confusing and seemingly incoherent effect of the policy interacting with real world constraints.

Neglect or abuse by medical and other professionals employed in detention centres can lead to distressing situations and even death. For example, the guards, doctors, and nurses who encountered Czech asylum seeker Jan Szamko at the Toronto immigration holding centre in 2011 did not detect that his odd behaviour was due to a lethal fluid buildup that compressed his heart, lowered his blood pressure, and subsequently shut down his bodily functions. On 8 December 2011, Szamko became the first immigration detainee to die in a Canadian facility. ${ }^{26}$ After accounting for former detainees who die after release from detention, the number of deaths caused by detention would continue to climb. ${ }^{27}$

\section{The Canadian Immigration Detention System}

Upon contextualization within a worldwide comparison of detention regimes, Canada can be seen to be shifting from a relatively progressive, holistic approach to a more typically draconian, punitive one. The legislative grounds for immigration detention in Canada can be found in sections 54 to 61 of the Immigration and Refugee Protection Act (IRPA), and in sections 244 to 250 of the Immigration Refugee and Protection Regulations (IRPR). The Immigration Refugee and Protection Regulations as well as the Citizenship and Immigration Canada Policy Manual on Detention provide directions on how immigration detention is to be enacted. A member of the Immigration Division (ID) of the Immigration and Refugee Board (IRB) reviews detention after 48 hours, then within the next 7 days, and then every subsequent period of 30 days. While the IRB oversees detention reviews and rules on appeals, the Canadian Border Services Agency is the detaining authority that is responsible for ports of entry and enforcing the IRPA.

There are three immigration holding centres (IHCs) in Canada: Toronto IHC with a capacity of 125 beds; Laval (Quebec) IHC with a capacity of 150 beds; and British Columbia IHC at the Vancouver International Airport with a capacity of 24 beds (although this third facility detains people only for up to 72 hours). So-called low-risk detainees are held in IHCs and high-risk detainees-people with criminal backgrounds, potential for flight risk, and/or mental health or behavioural problems-are held in provincial correctional or remand facilities not operated by the Canadian Border Services Agency (CBSA). Private security companies provide the guards that staff the Canadian IHCs. The CBSA claims that 74 per cent of detainees, which in some cases include children, are released within 48 hours. ${ }^{28}$

The Canadian immigration detention system is financially costly. In fiscal year 2008-9, detention and removal programs cost approximately $\$ 92$ million, of which detention costs amounted to $\$ 45.7$ million, or an average of $\$ 3,185$ per detained case. In 2008-09, the cost to Canadian taxpayers of detaining one person for one day in non-CBSA 
provincial facilities ranged from $\$ 120$ to $\$ 207^{29}$ The cost now stands at around $\$ 239$ per person per day. $3^{\circ}$

What happens to refugee claimants, children, and vulnerable people who become subject to detention in Canada? A small percentage of refugee claimants are detained on arrival. As a rule, children and youth (minors under 18 years of age) should not be held in immigration detention; if they are detained, it should be as a measure of last resort. Section 60 of the IRPA affirms "as a principle that a minor child shall be detained only as a measure of last resort, taking into account the other applicable grounds and criteria including the best interests of the child." ${ }^{11}$ In those exceptional cases where they are detained, international law requires governments to hold children in facilities and conditions appropriate to their age.32 Nonetheless, children are detained even when they are not security risks or dangers to the public. In 2008, an average of 77 children per month were detained, with the monthly average dropping to 31 in the first six months of 2009. 33 Some children may be detained as "guests" or because they are "accompanying their detained parent." These children are not included in the official statistical record and so the true number of detained children is higher than the official one cited above.

As regards vulnerable people, there is no systematic screening to identify them in the Canadian detention estate, and CBSA facilities do not offer any type of counselling services. ${ }^{34}$ If detainees are identified as exhibiting certain behavioural problems-such as aggressiveness-or mental illness-such as suicidal tendencies-then they are often transferred to prisons. For example, male asylum seekers in Ontario who exhibit behavioural or mental health problems are usually transferred to Central East Correctional Centre (the "Lindsay Super jail") if it is for a long period of time, and to the Toronto West Detention Centre, if it is for a shorter period of time or they have suicidal tendencies. 35 There is a related concern that immigration detainees are co-mingling with criminal inmates, and that twotiered mental health care is being provided in prisons with Canadian-born people being prioritized over newcomers. ${ }^{36}$

\section{The Far-Flung Locations of Detention Centres}

Since the IHCs are relatively small in capacity, dispersal amongst facilities is often the only strategy available when a large-scale detention order is made or when a large group of new arrivals is detained. For example, after the arrival of the MV Sun Sea, nearly 200 male passengers and crew were housed in a makeshift detention area set up in the yard of the Fraser Regional Correctional Centre; women went to the Alouette Correctional Centre, and those with children went to the Burnaby Youth Custody Services Centre. These facilities are located in the district of Maple Ridge, over 40 kilometres away from Vancouver.

The paucity of detention space in Canada raises a related concern: the unfairness of the chance of detention being highly correlated to whether the migrant or asylum seeker is arrested in Toronto and Montreal versus anywhere else in the state. The Canadian Council for Refugees notes, "Asylum seekers in Toronto and Montreal appear to be more readily detained than asylum seekers in other areas, because of the convenient availability of a detention centre. Furthermore, there are indications that in those cities the decision to detain or not detain is significantly influenced by how full the detention centre is and whether there is money in the detention budget or not." 37 If true, this scenario amounts to an arbitrary deprivation of liberty, a contravention of international legal rules on practising detention.

Although the IHCs are located close to the top three destination cities for migrants coming to Canada, the provincial jails are more difficult to get to without a car. The far-flung locations of the jails complicate the abilities of detainees' networks to visit and to provide support. Compounding these issues of access are centres' limited hours of visitation, detainees' difficulties gathering case-relevant evidence from detention, and the growing use of videoconference technology that allows for an immigration judge (and interpreter) in one courtroom to hear the case of an immigration detainee located in another courtroom some distance away. Cultural and linguistic barriers also compromise the abilities of some detainees to proceed fruitfully through their asylum and immigration adjudication procedures. $3^{8}$ Further, the mobility of detainees among the IHCs and the jails may also have an ancillary effect of presenting them as more transient and fleeting to actors that have an influence over their experiences, thereby leading to a reduction in care from figures such as guards, managers, and case workers. ${ }^{39}$ The difficulties of the conditions in provincial jails are multiplied in the context of mandatory detention: the typically long periods of detention spent in a space of relative isolation but hyper-exposure to guards, fellow detainees, and insecurity can lead to long-term mental and physical health consequences, a situation that is particularly egregious in light of the fate of release into the community that awaits many of the people subject to mandatory detention.

\section{Conclusions and Recommendations}

Although it has been used only once as of June 2014, the power of the C-31 "irregular arrivals" designation should not be underestimated. The designation signals a growth in reasons or justifications for mandatory detention in Canada. If recent legal challenges fail and C-31's detention of asylum 
seekers on the basis of their means of arrival is normalized into everyday Canadian immigration policy, the designation will work hand-in-hand with the DCO policy to create a system of more distrust and less protection for all new arrivals. The level of discretion in deciding the entries on the DCO list is out of proportion with the consequences for migrants from those countries. In light of the grave concerns highlighted by the public outcry over the DCO list, the minister of citizenship, immigration and multiculturalism should initiate a more robust conversation to justify the choices of countries included on the list and to validate the high level of public trust accorded to the minister via the discretionary decision-making powers.

Immigration detention systems expose an already vulnerable population to a potentially devastating situation in which their mental and physical health undoubtedly deteriorates. Instead of seeking measures to alleviate this burden, the Canadian government is using C-31 and other policy tools that effectively worsen it. Long-term detainees are both more psychologically and physically damaged from their experiences in IHCs and provincial jails, and more likely to remain in Canada after release. The policy of mandatorily detaining certain groups of non-citizens who are then expected to integrate and assimilate into Canadian society appears to be somewhat incoherent. Indeed, C-31 and the DCO policy are examples of a policy objective being effectively stymied by practical constraints, and the result may turn out to be antithetical to the original motivation for implementing the legislation.

It is also important to recognize that the damage from detention is not limited to those persons who are incarcerated: there is a ripple effect out from the IHCs and jails into the wider community, touching the detainee's networks but also ordinary residents who form negative impressions of detainees as criminals, deviants, and worse. ${ }^{40}$ Xenophobia and prejudice directed at detainees-including but not to those hailing from a $\mathrm{DCO}$ - can loop back to feed in to the sorts of moral panics that turned the arrivals of eight ships over a period of 14 years into an apparently acceptable justification for mandatory detention for one year. Scholars are observing a growing cohort of developed states that are calling on and exploiting their detention systems to amplify minor events into full-blown crises, thus rendering massive changes to immigration and asylum policies virtually indisputable in the public domain. ${ }^{41}$ In the wake of these eight ships and the subsequent creation of a DCO list and draconian detention provisions, it is possible that Canada should be added to this dubious group. The implications of this turn for the larger Canadian democratic polity should provide an interesting topic of research in another article.

\section{Notes}

1 Bilbo Poynter, "Canada Accused of Treating Tamil Asylum Seekers like Prisoners: After 500 Men, Women and Children Arrived off Vancouver Island in 2010, Some Were Held for up to a Year in Prison Facilities," Guardian, 29 November 2012, http://www.guardian.co.uk/world/2012/ nov/29/canada-accused-tamil-asylum-prisoners.

2 Alex Neve and Tiisetso Russell, "Hysteria and Discrimination: Canada's Harsh Response to Refugees and Migrants Who Arrive by Sea," University of New Brunswick Law Journal 62, no. 1 (2011): 37-46.

3 Stephanie J. Silverman, "Detention in Canada," Detention \& Asylum Research Cluster, 2013, http://refugeeresearch. net/ms/detention/detention-asylum-in-countries/detention-in-canada/. For further discussion of C-31, see, e.g., Petra Molnar Diop, “The 'Bogus' Refugee: Roma Asylum Claimants and Discourses of Fraud in Canada's Bill C-31," Refuge 30, no. 1 (2014): 67-80; Canadian Council for Refugees, "Overview of C-31 Refugee Determination Process," 21 February 2013, http://ccrweb.ca/en/refugee-reform.

4 Citizenship and Immigration Canada, "Designated Countries of Origin," 30 May 2013, http://www.cic.gc.ca/english/ refugees/reform-safe.asp.

5 Silverman, "Detention in Canada."

6 Citizenship and Immigration Canada, "Designated Countries of Origin."

7 Nicholas Keung, "Legal Aid Ontario Cutbacks Could Leave Desperate Refugees without Lawyers at Hearings," Toronto Star, 4 April 2013, http://www.thestar.com/news/ immigration/2013/o4/o4/legal_aid_ontario_cutbacks_ could_leave_desperate_refugees_without_lawyers_at_ hearings.html. Cf. Legal Aid Ontario / Aide Juridique Ontario, "Response to Enquiry on Legal Aid Changes on Immigration/Refugee Cases," http://www.legalaid.on.ca/ en/news/mediaenquiries/1304-05_torontostar.asp.

8 Diop, "'Bogus Refugee," 74.

9 Kristen Shane, "Critics Urge Rethink of Hungary's SafeCountry Label: 'Alarming' Election Results, Rising AntiSemitism Seen as Concerns; Hungarian Government Says It's Trying to Quash Radicalism," Embassy, 23 April 2014, http://www.embassynews.ca/news/2014/o4/22/criticsurge-rethink-of-hungaary's-safe-country-label/45444.

10 E. Arbel, J. Beaudoin, and E. Arbel, "Why Is There No Refuge for Roma Refugees?" Huffington Post, 21 December 2012, http://www.huffingtonpost.ca/stephanie-j-silverman/ roma-refugees-canada-immigration_b_2346160.html.

11 Diop, “"Bogus Refugee," 73.

12 Daniel Wilsher, "The Administrative Detention of NonNationals Pursuant to Immigration Control: International and Constitutional Law Perspectives," International and Comparative Law Quarterly 53, no. 1 (2008): 897.

13 S. J. Silverman, “Regrettable but Necessary'? A Historical Study of the UK Immigration Detention Estate and Its Opposition," Politics \& Policy 40, no. 6 (2012): 1131-57. 
14 François Crépeau, $A / H R C / 20 / 24$ : Report of the Special Rapporteur on the Human Rights of Migrants (Geneva: United Nations General Assembly, 2012), para. 68; UNHCR: UN Refugee Agency, Detention Guidelines: Guidelines on the Applicable Criteria and Standards relating to the Detention of Asylum-Seekers and Alternatives to Detention (Geneva: UNHCR: UN Refugee Agency, 2012): guideline 4.1. Since international law instructs governments to refrain from detaining vulnerable people-including unaccompanied elderly persons, survivors of torture or trauma, persons with mental or physical disabilities, pregnant or nursing women, and minors-detention of vulnerable people should only ever be a measure of last resort.

15 Amnesty International, Irregular Migrants and AsylumSeekers: Alternatives to Immigration Detention (London: Amnesty International Publications, 2009).

16 Stephanie J. Silverman, "Detention and Asylum in Canada and Abroad," Detention and Asylum Research Cluster, ed. J. Hyndman and D. Nakache (Toronto: Refugee Research Network, 2013). International legal and advocacy circles do not generally consider the second group-pre-decision asylum seekers-as an acceptable target for detention, as such cases often seem to be arbitrary or punitive and, hence, in violation of legal norms and conventions. I thank the Refuge anonymous reviewer for urging this important clarification.

17 Alfred de Zayas, "Human Rights and Indefinite Detention," International Review of the Red Cross 87, no. 857 (2005): 20.

18 Dora Schriro, Immigration Detention: Overview and Recommendations (Washington, DC: U.S. Department of Homeland Security, 2009), 4.

19 In the U.S. context, Juliet Stumpf refers to the merger of criminal and immigration law as the "crimmigration crisis" and argues that the purposeful mergers of these two bodies "primarily serve to separate the individual from the rest of US society through physical exclusion and the creation of rules that establish lesser levels of citizenship." Juliet Stumpf, "The Crimmigration Crisis: Immigrants, Crime, and Sovereign Power," American University Law Review 56, no. 2 (2006): 381 . Scholars argue that, throughout the Western world and in various ways, the "crimmigration crisis" has been augmented by the discourse of national security. This intermingling has led to the double or triple punishment of migrants. See, e.g., Ana Aliverti, "Making People Criminal: The Role of the Criminal Law in Immigration Enforcement," Theoretical Criminology 16, no. 4 (2012): 417-34; David Manuel Hernández, "Pursuant to Deportation: Latinos and Immigrant Detention," Latino Studies 6 (2008): 35-63; Anna Pratt, "Between a Hunch and a Hard Place: Making Suspicion Reasonable at the Canadian Border," Social \& Legal Studies 19, no. 4 (2010): 461-80; Karla Mari McKanders, "Unforgiving of Those Who Trespass against U.S.: State Laws Criminalizing Immigration Status," Loyola Journal of Public Interest Law 12 (2011): 331-63.
20 UN Human Rights Council, "Report of the Special Rapporteur on the Human Rights of Migrants, Jorge Bustamante," UN Doc. A/HRC/7/12, 25 February 2008, para. 50.

21 Galina Cornelisse, Immigration Detention and Human Rights: Rethinking Territorial Sovereignty (Leiden, Netherlands: Martinus Nijhoff Publishers, 2010), 21; A. Nethery and S. J. Silverman (2014). "Overview of 'Immigration Detention: The Migration of a Policy and Its Human Impact," Coherence and Incoherence in Migration Management and Integration: Policies, Practices and Perspectives, 7th Annual Conference of the Canadian Association for Refugee and Forced Migration Studies, Centre de Recherche en Droit Public, Université de Montréal, 2014.

22 Derrick Silove, Zachary Steel, and Charles Watters, "Policies of Deterrence and the Mental Health of Asylum Seekers," JAMA 284, no. 5 (2000): 608.

23 Caroline Fleay and Linda Briskman. "Hidden Men: Bearing Witness to Mandatory Detention in Australia," Refugee Survey Quarterly 32, no. 3 (2013): 128.

24 Katy Robjant, Rita Hassan, and Cornelius Katona, "Mental Health Implications of Detaining Asylum Seekers: Systematic Review," British Journal of Psychiatry 194 (2009): 30612; Janet Cleveland, Cécile Rousseau, and Rachel Kronick, "Bill C-4: The Impact of Detention and Temporary Status on Asylum Seekers' Mental Health," Brief for submission to the House of Commons Committee on Bill C-4, the Preventing Human Smugglers from Abusing Canada's Immigration System Act, http://oppenheimer.mcgill.ca/IMG/ pdf/Impact_of_Bill_C4_on_asylum_seeker_mental_ health_full-2.pdf.

25 Dennis Broeders. "Return to Sender? Administrative Detention of Irregular Migrants in Germany and the Netherlands," Punishment \& Society 12, no. 2 (2010): 182.

26 Nicholas Keung, "Not 'Good to Fly': The Tragic Death of a Roma Refugee," Toronto Star, 28 March 2011.

27 Alison Siskin, CRS Report for Congress: Health Care for Noncitizens in Immigration Detention (Washington DC: Congress, 2008), http://assets.opencrs.com/rpts/ RL34556_20080627.pdf, 22.

28 N. Keung, "Hundreds Held in Canada's Immigration Cells," Toronto Star, 18 November 2013, http://www.thestar.com /news/canada/2013/11/18/hundreds_held_in_canadas_ immigration_cells.html\#.

29 D. Nakache, The Human and Financial Cost of Detention of Asylum-Seekers in Canada (Geneva: United Nations High Commissioner for Refugees, 2012), 104, 39, 38.

30 Keung, "Hundreds Held."

31 Canadian Council for Refugees, "Detention and Best Interests of the Child," November 2009, http://ccrweb.ca/ documents/detentionchildren.pdf, 2.

32 Nakache, Human and Financial Cost, 4.

33 Canadian Council for Refugees, "Detention," 8, 7.

34 Nakache, Human and Financial Cost, 80.

35 Ibid., 82.

36 Ibid., 84 . 
37 Canadian Council for Refugees, "Submission on the Occasion of the Visit to Canada of the UN Working Group on Arbitrary Detention," 8 June 2005, http://ccrweb.ca/en/ submission-occasion-visit-canada-un-working-grouparbitrary-detention.

38 As well as knowing how to proceed through the asylum application and appeal processes, there is an assumption that detainees will abide by the rules of discourse. Materials are not always provided in translation. Further, some detainees who do speak English are not always able to engage meaningfully if there is no one available to explain the materials to them. Problems of comprehension are compounded if a detainee suffers from a mental impairment and/or cognitive disability. Further, the trauma of indefinite detention leads to significant deterioration in detainees' mental health. See, e.g., A. de Zayas, "Human Rights and Indefinite Detention," International Review of the Red Cross 87, no. 857 (2005): 15-38; Jane Herlihy, Kate Gleeson, and Stuart Turner, "What Assumptions about Human Behaviour Underlie Asylum Judgments?" International Journal of Refugee Law 22, no. 3 (2010): 351-66.

39 See Nicholas Gill, "Governmental Mobility: The Power Effects of the Movement of Detained Asylum Seekers around Britain's Detention Estate," Political Geography 28, no. 1 (2009): 186-96.

40 "Criminalizing migrants invokes a circular rationale that legitimizes detention: migrants might be criminals, necessitating detention; migrants must be criminals, because they are detained." Alison Mountz, Kate Coddington, R.
Tina Catania, and Jenna Loyd, "Conceptualizing Detention: Mobility, Containment, Bordering, and Exclusion," Progress in Human Geography 37, no. 4 (2013): 527.

41 Cetta Mainwaring, "Constructing a Crisis: The Role of Immigration Detention in Malta," Population, Space and Place 18, no. 6 (2012): 687-700; Alison Mountz and Nancy Ann Hiemstra, "Chaos and Crisis: Dissecting the Spatiotemporal Logics of Contemporary Migrations and State Practices," Annals of the Association of American Geographers 104, no. 2 (2013): 382-90.

Stephanie J. Silverman is a research associate at the Refugee Research Network and a post-doctoral fellow at the Nathanson Centre on Transnational Human Rights, Crime and Security, both at York University. She can be contacted at sj.silverman@gmail.com.

The author would like to thank Joseph H. Carens, Amrita Hari, Jennifer Hyndman, Petra Molnar, Daniel J. Lowinsky, Audrey Macklin, Delphine Nakache, and an audience at the 2013 meeting of the Canadian Association for Refugee and Forced Migration Studies for helpful information and feedback. The author would also like to pay special acknowledgement to the anonymous Refuge reviewer who went above and beyond in providing constructive criticism that greatly improved this article. Any mistakes remain the author's alone. 